\title{
Hematological profile of Astyanax bimaculatus under different offer of Lactobacillus sp
}

\author{
[Perfil hematológico de Astyanax bimaculatus sob diferentes \\ ofertas do Lactobacillus sp.]
}

A. Jatobá, M.O. Pereira, J.C.B. Rodhermel

Laboratório de Aquicultura, Instituto Federal Catarinense - Campus Araquari, SC

\begin{abstract}
The objective of this study was to evaluate the hematological and immunological parameters of yellowtail lambaris (Astyanax bimaculatus), fed with different frequencies of the probiotic (Lactobacillus spp.). Fishes were distributed into 20 experimental units and divided in five treatments: control $(0 \%), 25 \%$, $50 \%, 75 \%$ and $100 \%$ of probiotic supply. A higher presence of total leukocytes $\left(47.7010^{3} \mathrm{cell}^{\mathrm{c}} \mathrm{l}^{-1}\right)$, lymphocytes $\left(36.111^{3}\right.$ cell $\left.\mu l^{-1}\right)$ and monocytes $\left(11.5810^{3} \mathrm{cell}_{\mu \mathrm{l}^{-1}}\right)$ was verified in fish fed $100 \%$ of probiotic, showing a directly proportional ratio among the frequencies of the probiotic supply on the availability of circulating cells in the circulatory system $\left(\mathrm{R}^{2}\right.$ 094-0.97). Hematocrit (27.30-34.63\%), hemoglobin $\left(7.00-10.90 \mathrm{~g} \mathrm{dl}^{-1}\right)$, mean corpuscular volume $\left(4.21-5.4510^{-5} . \mathrm{pg}\right)$, mean corpuscular hemoglobin $\left(3.45-5.4010^{-6} . \mathrm{pg}\right)$, mean corpuscular hemoglobin concentration, $\left(2.99-4.35 \mathrm{~g} \mathrm{dl}^{-1}\right)$, total protein $\left(44.32-50.26 \mathrm{mg} \mathrm{ml}^{-1}\right)$ and total plasma immunoglobulin $\left(27.96-34.08 \mathrm{mg} \mathrm{ml}^{-1}\right)$ did not diverge among treatments. The frequency of the probiotic supply interferes with the hematological profile, although lactic acid bacteria were present in the same concentrations in the intestinal tract, regardless of the probiotic supply, there was an increase in circulating leukocytes, especially lymphocytes and monocytes, in lambari fed probiotic with more frequency.
\end{abstract}

Keywords: lactic acid bacteria; health, food management

\section{RESUMO}

O objetivo do presente trabalho foi avaliar os parâmetros hematológicos e imunológicos do lambari-dorabo-amarelo (Astyanax bimaculatus) alimentado com diferentes frequências de probiótico (Lactobacillus spp.). Os peixes foram distribuídos em 20 unidades experimentais e divididos em cinco tratamentos: controle (0\%), 25\%, 50\%, 75\% e 100\% de frequência na suplementação probiótica. Alta presença de leucócitos totais $\left(47,7010^{3}\right.$ células $\left.\mu^{-1}\right)$, linfócitos $\left(36,1110^{3}\right.$ células $\left.\mu^{-1}\right)$ e monócitos $(11,58$ $10^{3}$ células $\mu^{-1}$ ) em peixes alimentados com $100 \%$ de probiótico apresenta uma taxa diretamente proporcional entre as frequências da suplementação probiótica na disponibilidade das células no sistema circulatório $\left(R^{2}\right.$ 094-0,97). Hematócrito $(27,30-34,63 \%)$, hemoglobina $\left(7,00-10,90 \mathrm{~g} d L^{-1}\right)$, volume

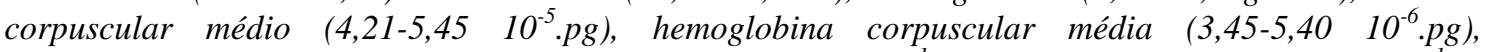
concentração de hemoglobina corpuscular média $\left(2,99-4,35 \mathrm{~g} \mathrm{dl}^{-1}\right)$, proteína total $\left(44,32-50,26 \mathrm{mg} \mathrm{ml}^{-1}\right) e$ imunoglobulina plasmática total (27,96-34,08 $\left.\mathrm{mg} \mathrm{ml}^{-1}\right)$ não divergiram entre os tratamentos. A frequência da suplementação probiótica interferiu no perfil hematológico. Embora as bactérias ácido láticas estejam presentes na mesma concentração no trato intestinal, independentemente da oferta de probiótico, houve um aumento na circulação de leucócitos, especialmente linfócitos e monócitos, nos lambaris alimentados com maior frequência.

Palavras-chave: bactéria ácido lática, saúde, manejo alimentar

Recebido em 21 de maio de 2018

Aceito em 19 de setembro de 2019

E-mail: jatobaadolfo@gmail.com 


\section{INTRODUCTION}

With the growing demand for food and the decline of natural fish stocks, production of captive fish has been increasingly stimulated and continues to grow across all continents in general. In South America, aquaculture plays an important role in food production and in the local economy, in addition to a large international presence with an impact on the global economy. This region is characterized by the production of different aquatic organisms, including marine fish, continental fish, shrimp, shellfish and frogs (Valladão et al., 2018).

Brazil is 14th in the list of the largest fish producers and produces especially continental water fish. Nile tilapia (Oreochromis niloticus) is the most important specie produced in Brazil being the 4th largest producer in the world of this species, even with a great diversity of native fish with potential for aquaculture (State..., 2016). Among these species, the yellowtail lambari (Astyanax bimaculatus) is an emerging species for Brazilian fish culture, capable of adapting to super intensive systems, can be reared in stocking densities between 2 and 7 fish per liter (Jatobá and Silva, 2015). However, intensive culture systems facilitate exposure of the fish to many microorganisms present in the environment, especially pathogens, due to the use of inadequate management techniques and / or lack of know-how about the most intensive production systems (Jatobá et al., 2016).

Probiotics reduce the need for investments in antimicrobials and parasiticides, consequently reducing the use of chemotherapeutics and their environmental impacts caused by fish culture (Hai, 2015), its use offers a very promising alternative to the use of antibiotics in aquaculture production systems (Vaseeharan and Ramasamy, 2003). Among beneficial microorganisms, some are classified as probiotics because of their ability to promote animal health (Jatobá et al., 2011; 2017; Merrifield et al., 2014; Hai, 2015; Ring $\varnothing$ and Lovino, 2010). Lactic acid bacteria (LAB) have demonstrated great efficacy for fish by enhancing growth performance (Jatobá et al., 2011; Standen et al., 2016), beneficial changes of the microbiota and morphophysiological of the gastrointestinal tract (Jatobá et al., 2017), besides being able to act as promoters of the immune system (Hai, 2015; Gobi et al., 2018).
Most probiotic studies have focused on proving the probiotic effects of different microorganisms, and the hematological and immunological parameters are commonly used to prove their effects and to determine the state of animal health, but few studies evaluate how the frequency of probiotic supply influence these parameters, as well as to evaluate its effects on the cellular and humoral immune. Thus, to understand how probiotics act on fish health, this research was carried out to evaluate the hematological and immunological parameters of yellowtail lambaris (A. bimaculatus) fed with different frequencies of the probiotic (Lactobacillus spp.).

\section{METHODOLOGY}

The study was carried out in the Laboratório de Aquicultura (LAQ), Instituto Federal Catarinense (IFC), campus Araquari, (Protocol number 0219/2017 approved by the animal ethics committee). The Lactobacilus strain CPQBA 1168-15 DRM-01 with proven probiotic effect in vitro and in vivo (Jatobá et al., 2017) and one hundred yellow tail lambari (A. bimaculatus), average weight $8.5 \pm 0.3 \mathrm{~g}$, were used.

The experimental units were divided into five treatments (Table. 1), with four replicates. Fish were distributed in 20 experimental units, 5 fish per experimental unit, with a capacity of 22L, equipped with recirculation system, canister filter and thermostats to keep constant temperature $\left(26-28^{\circ} \mathrm{C}\right)$. The dissolved oxygen maintained above $4.0 \mathrm{mg} \mathrm{L}^{-1}, \mathrm{pH}(6.9 \pm 0.2)$ and ammonia $\left(0.2 \pm 0.3 \mathrm{mg} \mathrm{L}^{-1}\right)$ were measured weekly.

Fish were fed a commercial diet four times a day $\left(08: 00,11: 00 ; 13: 00\right.$ and 16:00) $\left(\mathrm{GUABI}^{\circledR}\right.$, $1.7 \mathrm{~mm}, 36 \%$ crude protein and $6.5 \%$ ethereal extract, manufacturer's warranty levels), with $3 \%$ of their biomass. According to the protocols established by Jatobá et al. (2011), 10\% of inoculum was included in the probiotic diets with Lactobacillus strain and De Man, Rogosa and Sharpe medium (Lactobacillus MRS Broth, HiMedia Laboratories Pvt., India), and only sterile MRS medium (Lactobacillus MRS Broth, HiMedia Laboratories Pvt., India) in the control diet. Probiotic diets were only used when concentrations $\geq 1.0 \mathrm{x} \quad 10^{7} \mathrm{CFU} \cdot \mathrm{g}^{-1}$ were observed. 
Table 1. Probiotic supply frequency to yellowtail lambari (A. bimaculatus)

\begin{tabular}{llllll}
\hline \multirow{2}{*}{ Treatment } & Frequency & $08: 00$ & $11: 00$ & $14: 00$ & $16: 00$ \\
\hline \multirow{4}{*}{ Probiotic Supply } & $100 \%$ & $\mathrm{x}$ & $\mathrm{X}$ & $\mathrm{x}$ & $\mathrm{x}$ \\
& $75 \%$ & $\mathrm{x}$ & $\mathrm{X}$ & $\mathrm{X}$ & - \\
& $50 \%$ & $\mathrm{X}$ & $\mathrm{X}$ & - & - \\
& $25 \%$ & $\mathrm{x}$ & - & - & - \\
\hline
\end{tabular}

After 28 days of rearing and a $24 \mathrm{~h}$ period of starvation, all fish were anesthetized with Eugenol $\left(50 \mathrm{mg} \mathrm{L}^{-1}\right)$ and sacrificed by cerebral concussion, blood was collected from the caudal vessel using two $21 \mathrm{G} 3 \mathrm{~mL}$ syringes, one containing a drop of $10 \%$ EDTA as anticoagulant and one without. The blood with anticoagulant was used for hematology analysis. The blood without anticoagulant was incubated for $2 \mathrm{~h}$ at $25^{\circ} \mathrm{C}$, centrifuged at $1400 \mathrm{~g}$ for $10 \mathrm{~min}$ to obtain the serum, and stored at $-20^{\circ} \mathrm{C}$ for glucose analysis.

For hematological analyses, the total hemocyte count by Neubauer hemocytometer and hemoglobin concentration were used. Hematimetric absolute rates of mean corpuscular volume (MCV), mean corpuscular hemoglobin $(\mathrm{MCH})$ and mean corpuscular hemoglobin concentration (MCHC) were also obtained. Blood smear slides were stained with Giemsa and May Grünwald stain (Rosenfeld, 1947), total and differential leukocyte count were carried out as described by Jatobá et al. (2011). And for immunological analysis Total Plasmatic Protein (Reagente Bioquímico, Proteínas totais, LabTest, Brazil); glucose (G-TECH free ${ }^{\circledR}$, AccumedGlicomed, Brazil) and total immunoglobulin concentration (Siwicki and Anderson, 1993) were measured.

The intestinal tract of all fish from each experimental unit were removed and pooled for microbiological and histological tests. The pooled tract were homogenized and serially diluted $1: 10$ in $0.65 \%$ of $\mathrm{NaCl}$ sterile saline. Samples from each dilution were cultured in MRS (Lactobacillus MRS Agar, HiMedia Laboratories Pvt. Ltd., India), followed by incubation for $48 \mathrm{~h}$ at $35^{\circ} \mathrm{C}$, for lactic acid bacteria (LAB) counts. Colonies were reisolated and compared with morphology (GRAM method) of the probiotic strain offered.

All data were first subjected to Bartlett's analysis, to verify the homogeneity of variance, one-way ANOVA and significant differences among treatments were analyzed using the Student-Newman-Keuls (SNK) test. The total leukocyte, lymphocyte and monocyte count data were submitted to regression analysis and the coefficients evaluated for significance by the $t$ test. Microbiological data were $\log (\mathrm{x}+1)$ transformed. All tests were conducted at a $5 \%$ level of significance.

\section{RESULTS AND DISCUSSION}

Hematological and immunological changes are commonly observed in fish fed with probiotics (Jatobá et al., 2011, 2018a, 2018b; Gobi et al., 2018; Moraes et al., 2018), in lambaris fed with $100 \%$ frequency a higher number of total leukocytes, lymphocytes and circulating monocytes were observed than in the control treatment (Table. 2), while thrombocytes, erythrocytes, hematimetric and immunological parameters did not diverge among treatments (Table. 2). These results corroborate the data by Moraes et al. (2018) who offered the same probiotic to A. bimaculatus in $100 \%$ of the feeds.

The greater number of total leukocytes, lymphocytes and circulating monocytes in probiotic treatments suggesting greater immunocompetence, a finding that corroborates with the $16.4 \%$ higher survival of $A$. bimaculatus fed the same probiotic strain after experimental infection with Aeromonas hydrophila (Jatobá et al., 2017), as well as greater survival after being reared for 12 weeks in recirculation aquaculture system (Moraes et al., 2018). 
Table 2. Hematological variables of yellowtail lambari (Astyanax bimaculatus) fed with probiotic (Lactobacillus spp.), offered on different frequencies

\begin{tabular}{|c|c|c|c|c|c|}
\hline $\begin{array}{l}\text { Probiotic supply } \\
\text { Total and differer }\end{array}$ & $\begin{array}{l}0 \% \\
\text { tial leukocyte cc }\end{array}$ & $\begin{array}{l}25 \% \\
\text { unt }\end{array}$ & $50 \%$ & $75 \%$ & $100 \%$ \\
\hline $\begin{array}{l}\text { Erythrocyte } \\
\left(\mathrm{x} 10^{6} \mu \mathrm{l}^{-1}\right)\end{array}$ & $2.03 \pm 0.13^{\mathrm{a}}$ & $1.85 \pm 0.28^{\mathrm{a}}$ & $2.26 \pm 0.36^{\mathrm{a}}$ & $2.09 \pm 0.55^{\mathrm{a}}$ & $2.26 \pm 0.61^{\mathrm{a}}$ \\
\hline $\begin{array}{l}\text { Leucocytes } \\
\left(\times 10^{3} \mu 1^{-1}\right)\end{array}$ & $27.07 \pm 0.58^{\mathrm{d}}$ & $28.59 \pm 1.04^{\mathrm{d}}$ & $37.95 \pm 0.88^{c}$ & $42.40 \pm 1.56^{\mathrm{b}}$ & $47.70 \pm 0.67^{\mathrm{a}}$ \\
\hline $\begin{array}{l}\text { Thrombocytes } \\
\left(\times 10^{3} \mu 1^{-1}\right)\end{array}$ & $7.97 \pm 2.13^{\mathrm{a}}$ & $4.47 \pm 0.88^{\mathrm{b}}$ & $4.03 \pm 1.13^{\mathrm{bc}}$ & $3.01 \pm 0.55^{\mathrm{c}}$ & $5.12 \pm 2.62^{\mathrm{ab}}$ \\
\hline $\begin{array}{l}\text { Lymphocytes } \\
\left(\mathrm{x} 10^{3} \mu 1^{-1}\right)\end{array}$ & $22.57 \pm 0.63^{\mathrm{c}}$ & $23.22 \pm 0.73^{\mathrm{c}}$ & $30.18 \pm 0.54^{\mathrm{b}}$ & $31.64 \pm 1.52^{b}$ & $36.11 \pm 0.26^{\mathrm{a}}$ \\
\hline $\begin{array}{l}\text { Monocytes } \\
\left(\times 10^{3} \mu 1^{-1}\right)\end{array}$ & $4.65 \pm 0.97^{b}$ & $5.37 \pm 3.31^{\mathrm{ab}}$ & $7.77 \pm 1.80^{\mathrm{ab}}$ & $8.43 \pm 4.64^{\mathrm{ab}}$ & $11.58 \pm 4.19^{\mathrm{a}}$ \\
\hline \multicolumn{6}{|c|}{ Hematimetric parameters } \\
\hline Hematocrit (\%) & $32.60 \pm 1.75^{\mathrm{a}}$ & $27.30 \pm 3.64^{\mathrm{a}}$ & $34.07 \pm 4.17^{\mathrm{a}}$ & $32.43 \pm 3.96^{\mathrm{a}}$ & $34.63 \pm 2.25^{\mathrm{a}}$ \\
\hline${ }^{1} \mathrm{Hb}\left(\mathrm{g} \mathrm{dl}^{-1}\right)$ & $7.00 \pm 0.80^{\mathrm{a}}$ & $10.90 \pm 0.48^{\mathrm{a}}$ & $9.03 \pm 2.66^{\mathrm{a}}$ & $9.89 \pm 2.19^{\mathrm{a}}$ & $9.03 \pm 0.51^{\mathrm{a}}$ \\
\hline${ }^{2} \mathrm{MCV}\left(10^{-5} \cdot \mathrm{pg}\right)$ & $5.40 \pm 2.89^{\mathrm{a}}$ & $4.86 \pm 1.74^{\mathrm{a}}$ & $4.21 \pm 1.62^{\mathrm{a}}$ & $4.77 \pm 6.33^{\mathrm{a}}$ & $4.24 \pm 1.08^{\mathrm{a}}$ \\
\hline${ }^{3} \mathrm{MCH}\left(10^{-6} \cdot \mathrm{pg}\right)$ & $3.45 \pm 2.81^{\mathrm{a}}$ & $4.37 \pm 1.77^{\mathrm{a}}$ & $4.21 \pm 1.62^{\mathrm{a}}$ & $4.77 \pm 6.33^{\mathrm{a}}$ & $4.24 \pm 1.08^{\mathrm{a}}$ \\
\hline${ }^{4} \mathrm{MCHC}\left(\mathrm{g} \mathrm{dl}^{-1}\right)$ & $2.99 \pm 0.16^{\mathrm{a}}$ & $3.99 \pm 0.85^{\mathrm{a}}$ & $4.35 \pm 1.97^{\mathrm{a}}$ & $3.38 \pm 0.61^{\mathrm{a}}$ & $3.86 \pm 0.47^{\mathrm{a}}$ \\
\hline \multicolumn{6}{|c|}{ Immunological parameters } \\
\hline Glucose $\left(\mathrm{mg} \mathrm{dl}^{-1}\right)$ & $138.33 \pm 30.52^{\mathrm{a}}$ & $166.86 \pm 26.92^{\mathrm{a}}$ & $163.86 \pm 29.27^{\mathrm{a}}$ & $145.22 \pm 11.75^{\mathrm{a}}$ & $132.00 \pm 14.40^{\mathrm{a}}$ \\
\hline${ }^{5} \mathrm{TTP}\left(\mathrm{mg} \mathrm{ml}^{-1}\right)$ & $48.04 \pm 6.27^{\mathrm{a}}$ & $49.25 \pm 4.15^{\mathrm{a}}$ & $44.32 \pm 15.21^{\mathrm{a}}$ & $47.64 \pm 10.73^{\mathrm{a}}$ & $50.26 \pm 4.93^{\mathrm{a}}$ \\
\hline${ }^{6} \mathrm{TPI}\left(\mathrm{mg} \mathrm{ml}^{-1}\right)$ & $29.60 \pm 4.00^{\mathrm{a}}$ & $34.08 \pm 11.13^{\mathrm{a}}$ & $32.75 \pm 8.80^{\mathrm{a}}$ & $27.96 \pm 4.62^{\mathrm{a}}$ & $32.03 \pm 12.69^{\mathrm{a}}$ \\
\hline
\end{tabular}

*Different letters indicate significant differences $(\mathrm{P}<0.05)$ between treatments in ANOVA and SNK test. ${ }^{1}$ Hemoglobin concentration; ${ }^{2}$ Mean corpuscular Volume $=$ Hematocrit $\times 10 /$ Erythrocyte; ${ }^{3}$ Mean corpuscular Hemoglobin $=$ Hemoglobin concentration $\times 10 /$ Erythrocyte; ${ }^{4}$ Mean Corpuscular Hemoglobin Concentration = Hemoglobin concentration x 100/Hematocrit; ${ }^{5}$ Total Plasmatic Protein; and ${ }^{6}$ Total plasmatic immunoglobulin.

The hematological profile of fish is an important indicator of fish health, the equality to immunological and hematimetric among treatments suggests the absence of stress and pathologies, as well as all fish were healthy and well adapted to the experimental management (Ranzani-Paiva and Silva-Souza, 2004). Higher presence of total leukocytes, lymphocytes and circulating monocytes in fish fed $100 \%$ of probiotic is an indicator of fish health and reflects the enhancement of the cellular defense mechanism (Sopinska, 1985; Ranzani-Paiva and Silva-Souza, 2004).

Animals fed with probiotics, kept under proper conditions and submitted to correct handling, usually present few significant differences in their hematological data, considering that under these conditions the possibility of contact with pathogenic microorganisms is reduced (Meurer et al., 2007). Factors including genetic traits, seasonal factors, the environmental temperature, pollution, handling and crowding stress, diets and food additives, effects of diseases and vaccination, as well as immunostimulants and probiotics can interfere with the immune system of fish (Magnadóttir, 2006). Figure. 1 shows a directly proportional ratio among the frequencies of the probiotic supply on the availability of circulating cells in the circulatory system. This analysis suggested that the higher frequency in the supply of probiotics stimulates the production of total leukocytes, especially lymphocytes and monocytes, while total plasmatic protein and total plasmatic immunoglobulin did not have any relationship with the frequency of probiotic supply (Figure 2.) Son et al. (2009) observed upregulation of innate cellular and humoral immune responses to groups (Epinephelus coioides) fed diets containing Lactobacillus plantarum at 0 (control), $10^{6}, 10^{8}$, or $10^{10}$ colonyforming units (cfu) $\mathrm{kg}^{-1}$ for 4 weeks. However, these authors did not evaluate the effect of different concentrations of probiotic in the diet on fish.

The results of this study may suggest that the action of the probiotic, dependent on the bacterial strain, may act in different ways, specifically this drum strain demonstrated greater 
capacity to modulate the profile of immune defense cells, while the humoral parameters, such as protein and plasma immunoglobulin did not change. Perhaps the humoral defenses are better evaluated after experimental challenges, such as thermal shocks, pathological infections or even inadequate handling.

All treatments with probiotic, regardless of the frequency of supply, presented higher LAB counts (Figure. 3) and the isolated colonies presented the same morphology of the probiotic strain offered. This result suggests that although LAB counts are similar among probiotic treatments $(25,50,75$ and 100\%), the host immune system reacts differently according to the frequency of Lactobacillus spp. supplied. Many strains of LAB beneficially change the intestinal tract (Ring $\varnothing$ and Lovino, 2010), Jatobá et al. (2017) observed decrease of vibrios, staphylococcus and pseudomonas counts, besides higher length, width and perimeter of the villi in intestinal tract of yellowtail lambari fed probiotic (same strain used in this work).
In recent works, Jatobá el al. (2018a) observed that the different supply of Lactobacillus spp. to lambaris results in distinct microbiological, hematological and zootechnical responses because the presence of the probiotic in the digestive tract does not guarantee the hematological changes necessary to improve the immunocompetence, as well as improved growth performance. In that research only lambaris fed with probiotic supplemented in $100 \%$ of the feeds showed improvement in the growth performance. Similar results were observed for Nile tilapia, in which fish fed with $50 \%$ and $100 \%$ probiotic supplemented in the diets presented higher growth performance (Jatobá el $a l ., 2018 b)$. The difference in the result between these species may be related to the length of the digestive tract, in which tilapia has an intestinal tract 3 to 5 times larger than its total compartment, while lambari has a short intestinal tract (smaller than its length), reducing probiotic residence time, requiring constant supply to improve probiotic acting.

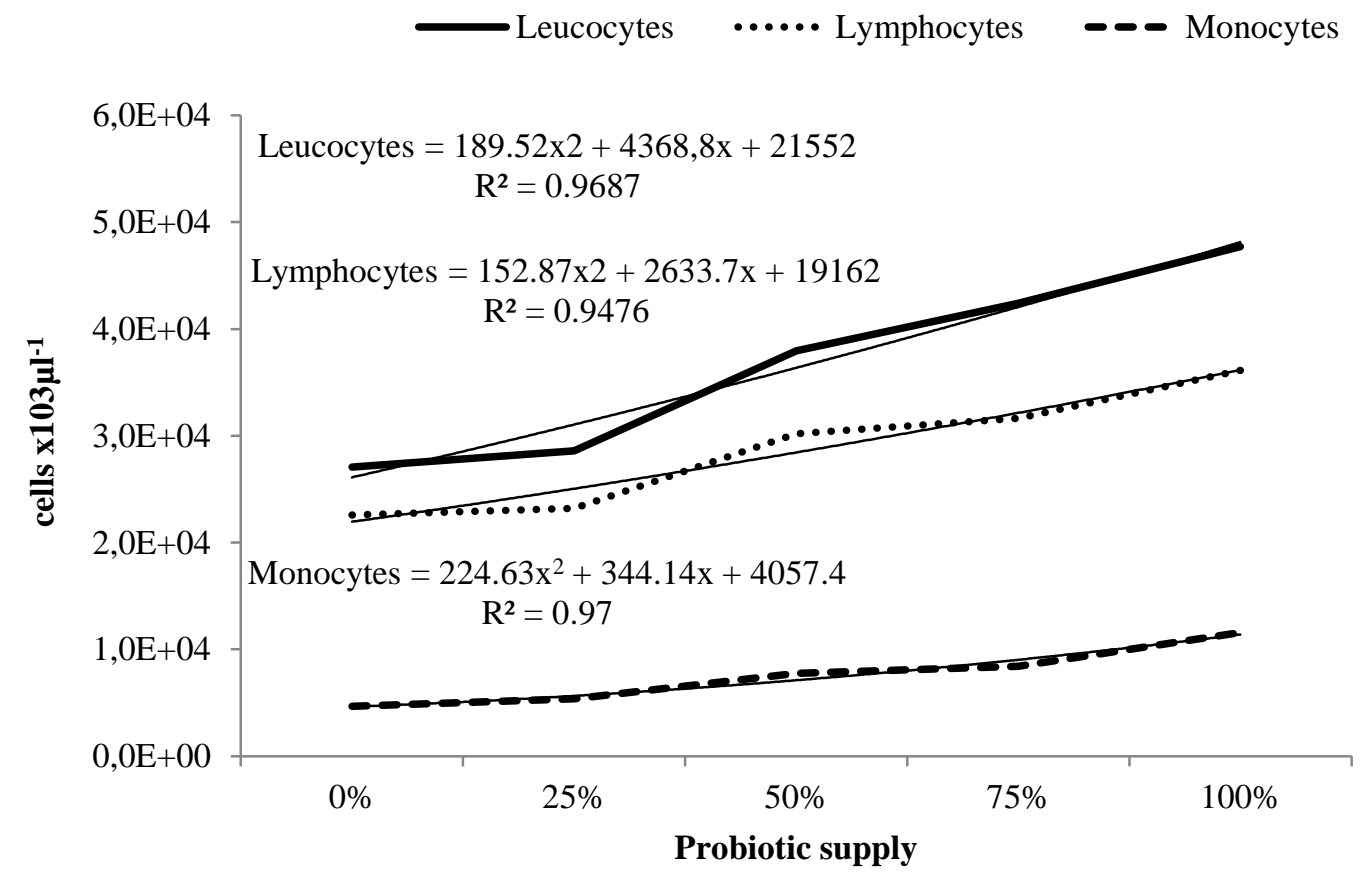

Figure 1. Count of total lymphocytes, monocytes and leukocytes of yellowtail lambari (A. bimaculatus) supplemented with probiotic (Lactobacillus spp.), offered in different frequencies. Second-order polynomial regressions are significant $(\alpha<0.05)$. 


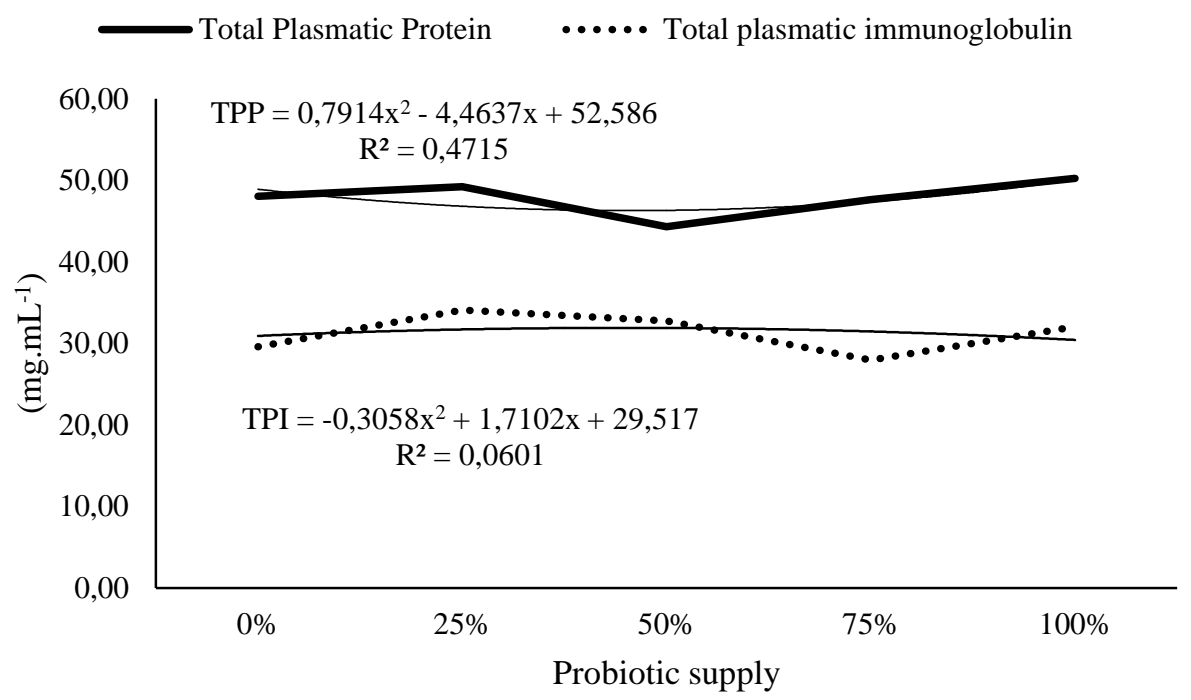

Figure 2. Total Plasmatic Protein (TPP) and Total Plasmatic Immunoglobulin (TPI) of yellowtail lambari (A. bimaculatus) supplemented with probiotic (Lactobacillus spp.), offered in different frequencies.

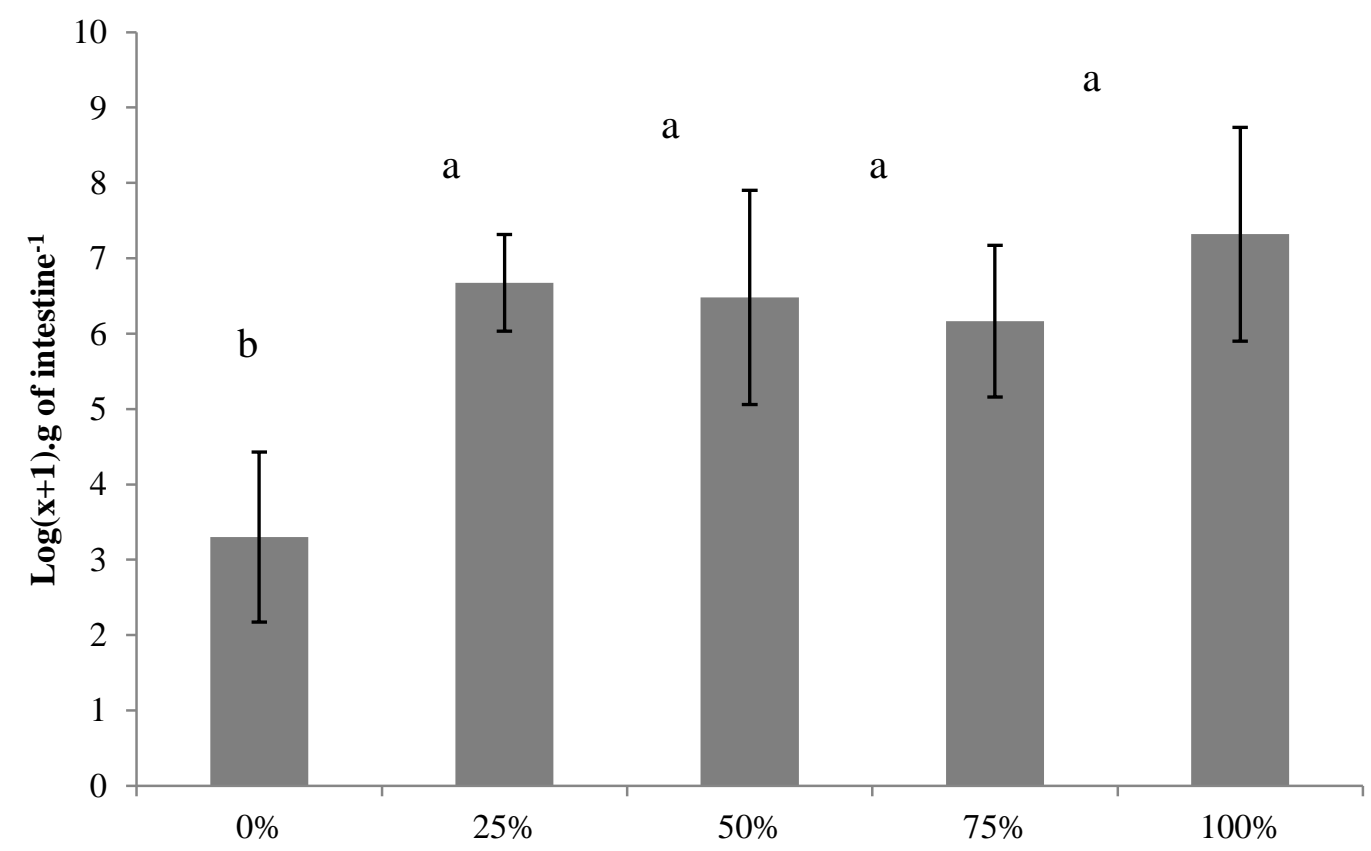

Figure 3. Acid lactic bacterial counts $\left(\log \mathrm{UFC} \mathrm{mL}^{-1}\right)$ of intestinal tract of yellowtail lambari $(A$. bimaculatus) supplemented with probiotic (Lactobacillus spp.), offered in different frequencies. Different letters indicate significant differences $(\mathrm{P}<0.05)$ between treatments in ANOVA and SNK test.

\section{CONCLUSION}

The frequency of probiotic supply interferes in the yellowtail lambari hematological profile (increasing leukocytes, especially lymphocytes and monocytes), however it does not alter variables of the innate immunity (total plasmatic protein and total plasmatic immunoglobulin) without challenges (experimental infection, stress, thermal shock or any other). The frequency of probiotic supply is more important to enhance the number of defense cells than LAB concentrations in the intestinal gut to yellowtail lambari (Astyanax bimaculatus). 


\section{ACKNOWLEDGEMENTS}

The authors of this study acknowledge Conselho Nacional de Desenvolvimento Científico e Tecnológico (CNPq) for support (Processo 460362/2014-3) and offering scholarship (PIBITI IFC/CNPq) for the development of the project; GUABI for financing the diets used; and Pâmela Stolf, Klayton Moraes and Luiz Sérgio Moreira for technical support.

\section{REFERENCES}

GOBI, N.; VASEEHARAN, B.; CHEN J.C. et al. Dietary supplementation of probiotic Bacillus licheniformis Dahb1 improves growth performance, mucus and serum immune parameters, antioxidant enzyme activity as well as resistance against Aeromonas hydrophila in tilapia Oreochromis mossambicus. Fish Shellfish Immunol., v.74, p.501-508, 2018.

HAI, N.V. Research findings from the use of probiotics in tilapia aquaculture: a review. Fish Shellfish Immunol., v.45, p.592-597, 2015.

JATOBÁ, A.; KLIPP, S.P.; HOPPE, R. Primeiro relato de Francisella noatunensis subespécie orientalis no sul do Brasil-relato de caso. Acta Vet. Bras., v.10, p.172-176, 2016.

JATOBÁ, A.; MORAES, A.V.; STECKERT, L.D.; JESUS, G.F.A. Selection of autochtone probiotic for Astyanax bimaculatus. Arq. Bras. Med. Vet. Zootec., v.69, p.1645-1652, 2017.

JATOBÁ, A.; MORAES, K.N.; RODRIGUES, E.F. et al. Frequency in the supply of Lactobacillus influence its probiotic effect for yellow tail lambari. Ciênc. Rural, v.48, p.1-10, 2018a.

JATOBÁ, A.; PEREIRA, M.O.; VIEIRA, L.M. et al. Action time and feed frequency of Lactobacillus plantarum for Nile tilapia. Arq. Bras. Med. Vet. Zootec., v.70, p.327-332, 2018 b.

JATOBÁ, A.; SILVA, B.C. Stocking density in the juvenile production of two characins species in a recirculating system. Arq. Bras. Med. Vet. Zootec., v.67, p.1469-1474, 2015.

JATOBÁ, A.; VIEIRA, F.N.; BUGLIONENETO, C.C. et al. Diet supplemented with probiotic for Nile tilapia in polyculture system with marine shrimp. Fish Physiol. Biochemi., v.37, p.725-732, 2011.
MAGNADÓTTIR, B. Innate immunity of fish (overview). Fish Shellfish Immunol., v.20, p.137151, 2006.

MERRIFIELD, D.L.; BALCÁZAR, J.L.; DANIELS, C. et al. Indigenous lactic acid bacteria in fish and crustaceans. In: MERRIFIELD, D.L.; RING $\varnothing$, E. (Eds.). Aquaculture nutrition: gut health, probiotics and prebiotics. New Jersey: John Wiley \& Son, 2014. p.128-168.

MEURER, F.; HAYASHI, C.; COSTA, M.M. et al. Saccharomyces cerevisiae as probiotic for Nile tilapia fingerlings submitted to a sanitary challenge. Rev. Bras. Zootec., v.36, p.1219-1224, 2007.

MORAES, A.V.D.; PEREIRA, M.D.O.; MORAES, K.N. et al. Autochthonous probiotic as growth promoter and immunomodulator for Astyanax bimaculatus cultured in water recirculation system. Aquacul. Res., v.49, p.2808-2814, 2018.

RANZANI-PAIVA, M.J.T.; SILVA-SOUZA, A.T. Hematologia de peixes brasileiros. In: RANZANI-PAIVA, M.J.T.; TAKEMOTO, R.M.; LIZAMA, M.A.P. Sanidade de organismos aquáticos. São Paulo: Varela, 2004. p.89-120.

RINGØ, E.; LØVMO, L.; KRISTIANSEN, M. et al. Lactic acid bacteria vs. pathogens in the gastrointestinal tract of fish: a review. Aquacul. Res., v.41, p.451-467, 2010.

ROSENFELD, G. Corante pancrômico para hematologia e citologia clínica. Nova combinação dos componentes do May-Grünwald e do Giemsa num só corante de emprego rápido. Mem. Inst. Butantan, v.20, p.329-334, 1947.

SIWICKI, A.K.; ANDERSON, D.P. Immunostimulation in fish: measuring the effects of stimulants by serological and immunological methods US Fish Wildl. Serv. IFI, v.1, p.1-17, 1993.

SON, V.M.; CHANG, C.C.; WU, M.C. et al. Dietary administration of the probiotic, Lactobacillus plantarum, enhanced the growth, innate immune responses, and disease resistance of the grouper Epinephelus coioides. Fish Shellfish Immunol., v.26, p.691-698, 2009. 
SOPINSKA, A. Effect physiological factors, stress, and disease on hematologic parameters of carp, with a particular reference to the leukocyte patterns: III. Changes in blood accompanying branchionecrosis and bothriocephalosis. Acta Ichthyol. Piscatoria, v.15, p.141-165, 1985.

STANDEN, B.T.; PGGS, D.L.; RAWLING, M.D. et al. Dietary administration of a commercial mixed-species probiotic improves growth performance and modulates the intestinal immunity of tilapia, Oreochromis niloticus. Fish Shellfish Immunol., v.49, p.427-435, 2016.
STATE of the world fisheries and aquaculture 2016. Contributing to food security and nutrition for all. Rome: FAO, 2016.

VALLADÃO, G.M.R.; GALLANI, S.U.; PILARSKI, F. South American fish for continental aquaculture. Rev. Aquacul., v.10, p.351-369, 2018.

VASEEHARAN, B.A.R.P.; RAMASAMY, P. Control of pathogenic Vibrio spp. by Bacillus subtilis BT23, a possible probiotic treatment for black tiger shrimp Penaeus monodon. Lett. Appl. Microbiol., v.36, p.83-87, 2003. 